Editor Científico: Arnoldo José de Hoyos Guevara Editora Assistente: Lívia Lopes Aguiar

Avaliação: Melhores práticas editoriais da ANPAD

\title{
SUSTAINABLE LEADERSHIP: A SEARCH FOR BETTER RESULTS FROM INTERACTIONS
}

\section{Liderança Sustentável: Uma busca por melhores resultados das Interações}

\section{Danilo Nunes, Arnoldo Jose de Hoyos Guevara}

Pontificia Universidade Católica - São Paulo, Brazil

E-mail: danilo1959@uol.com.br, arnoldodehoyos@yahoo.com.br

\begin{abstract}
It is understood that if there is leadership, it is because there are leaders and leds. Leadership is the process that results from the interaction and integration of those two subjects. It is a fact that the effective exercise of leadership will exist when there is not only concern with the hierarchical relationship itself, but also with the perception of those involved. The strengthening of the collective will take place when the characteristics of each group member are strengthened. Diversity is when we talk about behavior, respect for diversity, and people's competences and skills. The sum of individualities constitutes the broad sense of the group. The approach that followers want and expect from their leaders leads us several reflections to the point that we say that an executive can be led by someone from another hierarchical levels, provided that in a specific task, the group is the basis of construction. But it is very difficult to see this reality in the actual cooperative context; however much the concepts are shifting to an wide scenario, more flexible, more heterogeneous, a significant portion of those in leadership positions still reside under a traditional culture background in which the hierarchy is the basis of organizational power and almost the only reference to it. On the basis of this study research, it is stimulating the search for the answer to the following disquiet: How can leadership contribute to sustainability goals? In the dynamics of groups as an interactive and integrative organizational practice, we seek a way of acting where leaders and leds find the best ways to achieve these results Keywords: Leadership; Group; Integration; Cooperation
\end{abstract}

Resumo: : Entende-se que, se há liderança, é porque existem líderes e liderados. Liderança é o processo que resulta da interação e integração desses dois assuntos. O fato é que o exercício efetivo da liderança existirá quando não houver apenas preocupação com a relação hierárquica em si, mas também com a percepção dos envolvidos. O fortalecimento do coletivo ocorrerá quando as características de cada integrante do grupo forem fortalecidas. A diversidade é quando falamos de comportamento, respeito à diversidade e competências e habilidades das pessoas. A soma das individualidades constitui o sentido amplo do grupo. A abordagem que os seguidores querem e esperam de seus líderes nos leva a várias reflexões ao ponto de dizermos que um executivo pode ser conduzido por alguém de outros níveis hierárquicos, desde que em uma tarefa específica, o grupo seja a base da construção. Mas é muito difícil ver essa realidade no contexto cooperativo atual; por mais que os conceitos estejam mudando para um cenário amplo, mais flexíveis, mais heterogêneos, uma parcela significativa dos que ocupam cargos de liderança ainda residem sob uma cultura tradicional em que a hierarquia é a base do poder organizacional e quase a única referência a ele. Com base nessas considerações se busca a resposta para a seguinte inquietação: Como a liderança pode contribuir para os objetivos de sustentabilidade? $\mathrm{Na}$ dinâmica dos grupos como uma prática organizacional interativa e integrativa, buscamos uma forma de agir onde líderes e liderandos encontrem as melhores formas de alcançar esses resultados. Palavras-chave: Estresse acadêmico; Procrastinação ativa; Procrastinação passiva; Auto eficácia acadêmica; Performance acadêmica 


\section{INTRODUCTION}

The procedure of interaction between humanbeings is present in every human organization and is what implies the direction of activities and their results. Zimerman(Zimerman, 1997) states that "every individual is a group (in the means that as their inner world has groups of introjected characters that coexist and interact with each other) in the same way as any group can behave as an individuality". According to Pichon-Rivière(Pichon-Rivière, 1991), a group is every batch of people jointed by each other by constants of time and space, and articulated by their reciprocal internal representation.

The group proposes explicitly and implicitly to the consummation of a task that constitutes its purpose, interacting through structures of adjudication and assumption of roles. Therefore, we cannot think in the individual, without taking into account their different circumstances, their different moments and their influence in the construction of the roles assumed in their lives, since ours birth we are inserted in a group, being the family group, our first interaction.

In his book, The Fifty Discipline, Peter Senge (Peter Senge, 2005) explains that in group learning collective skills tend to be superior to the individual skills, and that through dialogic practices the group can expand their perspectives on Facts, generating more fruitful and relevant ideas. When the group learns, in addition to producing extraordinary results, its members develop faster than in the individual sense. The author also argues that team learning is the process of aligning and developing the team's ability to create results that its members really want and that it is through learning that we become capable of doing something we have never been able to do, that is, it gives us the power of recreation.

Groups are spaces where people occupy symbolically determined positions and these positions are responsible for the way in which the relations between them are constituted. The space occupied by a certain member of the group is not necessarily a physical space, it is an abstract space. Human organization is not only a group, a team, a group of individuals, for each one has its own feelings, interests, desires, frustrations, physical and social needs related to its own life history. True human relationships are useful and important to practice, because they avoid misbehavior that has been generated by dissatisfaction; keep individual and collective wellness, and, above all, provide security, peace and tranquility to individuals and businesses.

The purpose of this study is to explore the processes of integration of leadership in organizational environments focusing on the behavioral issues of individuals, leaders and leds. Practical approaches to group dynamics are central to human relations at work, and their probable affective consequences may lead the team to achieve higher performance. It is understood that this is a path that can, in an effectiveway, lead us to reach the proposed goal.

The process of leadership becomes more and more procedural and circumstantial and dependent on the recognition that those involved have about the practices adopted. As organizations become more vulnerable to market demands and competitive relationships, their leaders and leds tend to become more vulnerable to influence either personally or institutionally.

Fleury(Fleury, 2001) claims that it is necessary to observe how the group learns and how it adjusts individual knowledge and beliefs. According to this latest, it is important not only to interpret them, but also to try to integrate them into shared collective patterns. This can be a motivational element in the learning process. When we reflect on the different periods and situations in the life of human beings, it is almost impossible to imagine an interpretation without taking into account the circumstances or the influences of these in the constitution of different roles that is assumed in the different groups through which it passes. According to the Spanish philosopher Ortega y Gasset told us in his masterpieceMeditations of Quixote: "I am myself and my circumstance, and if I do not save it, I do not save myself"(Ortega Y Gasset, 1967). 


\section{LEADERSHIP AND INTERACTIONS FOR A SUSTAINABLE SOCIETY}

We must observe in the management literature, the approach of different types of leadership, which brings us to the understanding that we can also have different types of profiles of leaders in the corporate market. Some of these concepts stand out:

Autocratic Leader: uses directional and rigid techniques. He presents as a characteristic feature his inability to discriminate between role and person, confusing himself with the group (PichonRivière, 1991);

Democratic Leader: "an ideal role that can be assumed in group work. The exchange between the leader-coordinator and the group takes place in the form of a permanent spiral, where the processes of teaching and learning are linked, forming a feed and feedback unit";

Leader Laissez Faire: "he is the one who delegates to the group degree of autonomy and which only partially assumes his functions of analysis of the situation and orientation of the action";

Demagogic leader: "he is impostor in that, with an autocratic structure, he shows an appearance of democracy, sometimes falling into situations of laissez-faire, as a result of these contradictory attitudes".

This plurality perpetuates itself and it is difficult to imagine when there will be an equilibrium point that is at least reasonable, since the profile of leaders is too much on the principles of leadership exercised primarily on the look of process and practice, at least on an empirical basis, that there is, in fact, a concern in terms of good managers and not necessarily good leaders.

Senge says that there are only a few large companies that reach the average age compared to one person, because in most companies that disappear, there are many early indications of problems. However, these indices are ignored, even when some managers are aware of them. The organization as a whole cannot recognize the imminent threats, understand the implications or find alternatives to them, in a clear criticism of the models applied to the decision-making process of organizations. It's not a coincidence that most organizations have learning difficulties. The way they are designed and managed, the way positions are defined and, most importantly, how we have all been taught to think and interact (not only in organizations, but in a wide perspective), all create crucial learning. These occur independently of the great efforts of bright and committed professionals.

In delving further into business practice, and in this case also supplied by the academy in general, it is the concept and practice of leadership that is almost exclusively associated with the role and profile of leaders when it is known that the importance of values, beliefs, culture and profiles of the leaders gained strength and dimension when building the collective that is not only a social tonic but also a business necessity.

This scenario reminds us of concerns that, if we are not to be seduced by preliminary concepts formed by common sense, we must search for elements that will lead us to integrated and interrelated actions necessary so that we can form leaderships to attend to the different forms of governance within Responsible and sustainable principles.

Executive education plays a fundamental role in the health of an organization, in the generation ofnew knowledge and in the definition of valuesfocused on sustainability and innovation, such as:

1) Develop responsible and aware leaders of their role in building an increasingly promising future.

To reach this goal, it is necessary to walk safely and convinced that the choices, if not the best, should be the most appropriate for the organizational context. It is understood that a special look should bedirected to what are proposed as specific objectives, such as: 
2) Establish a governance model that allows generating, monitoring and improving results;

3) Propose teaching methods that allow the application of active learning methodologies;

4) Dimension the transversal themes that support the concept of organizational sustainability.

It is understood as a concept of sustainability.

Organizational sustainability is the "principle that ensures that our actions today will not limit the economic, social and environmental options for future generations" and understands that organizational performance is based on three pillars, that is, the triple bottom line, which are: economic, environmental and social results. These pillars correlate in the form of ecoefficiency, fair trade practices and social insertion and environmental justice (Elkington, 2001).

In accordance with this understanding evidence that the sustainable leadership is a shared responsibility, i.e, it's not only the leader or the lids, but it is an issue for everybody. It is a leader responsibility to stimulate this process and evaluate, continually, if their proposals and actions area having the necessary impact and are required for the collective construction. The Sustainable leadership needs, certainly become a commitment of all.

\section{THE PATH OF SUSTAINABLE LEADERSHIP}

Revisiting the literature and contemporary practices that can give substance to the proposal of this study, that is, finding ways to sustain leadership with alternative models that privilege group work as a differential in this process, gains more and more space in the corporate context, the PRME Principles for Responsible Management Education a global United Nations (UN) platform for voluntary engagement for organizations, business schools and higher education institutions. According to the website "www.prmebrazil.com.br", this platform is supported by six principles, which were created based on international values, such as the "Ten principles of the United Nations Global Compact"

Principle 1 - Purpose: to develop students' capacities to be sustainable future generators for business and society at large and work towards an inclusive and sustainable global economy.

Principle 2 - Values: incorporate in academic activities and curriculum the values of global social responsibility as portrayed in international initiatives, such as the United Nations Global Compact.

Principle 3 - Methodology: create teaching structures, materials, processes and environments thatenable effective learning experiences for responsible leadership.

Principle 4 - Research: Participate in conceptual and empirical research to advance understanding about the role, dynamics and impact of corporations in creating sustainable social, environmental and economic value.

Principle 5 - Partnerships: interact with business corporation's managers to increase knowledge about their challenges in meeting social and environmental responsibilities and to explore jointly effective approaches to address these challenges

Principle 6 - Dialogue: facilitate dialogue and support the debate among educators, students, businesses, governments, consumers, the media, civil society organizations and other stakeholder groups on critical issues related to global social responsibility and sustainability. 
By reading these principles, it is understood that it is more than an opportunity for change, but a real push for organizations to become aware of the need for a general review of concepts and practices related to their purposes, that is evidence the urgency in incorporating into the "institutional DNA" programs and projects aimed at the formation of people supported by a broader and culturally understood concept of social justice.

The PRME promotes the reconstruction of more effective and profitable channels of communication in the opening of the dialogue between academia, social segments and what represents the corporate market and its stakeholders.

The proposal is for an acting line based on the principles of humanized management. The propagation, dissemination and sustainable awareness are important aspects for implanting corporate governance models aligned with organizational objectives. This strategic adaptation is no longer a concern and has become a constant in the organizational context.

The generation of good results is the consequence of several factors, your main priority, if not the main one, the ethical and cultural commitment and the formation of human capital. Evaluating the guiding principles of this program, which give us a broad possibility of actions, but focusing on what is proposed in this study, we are faced with principle 3 that establishes: creating teaching structures, materials, processes and environments that enable effective learning experiences for Responsible leadership.

In accordance with the concepts already discussed in this study, the following reflection is made: What practices or management proposals can we work to achieve better results based on the basic principles of sustainable leadership?

\section{The dynamics of "groups" and "the groups"}

Among the alternatives that are most feasible for the development of this proposal, and searching for the basis for the construction of scenarios that lead us not only to reach the proposed objectives, but also to establish the ways for a certain answer to the resulting problem, there are discussions about the dynamics The group's functioning, its tacit and sometimes juridical rules, its objectives, its deliberative criteria and its rules of conduct.

Schutz(Schutz, 1978), in his Theory of Interpersonal Needs, finds that each person seeks to integrate into a group as long as their fundamental and interpersonal needs are content. These needs are basic because they must be experienced by every human being. They are also interpersonal because only in group and group can be satisfied adequately. Altogether Schutz points to three needs: inclusion, control and affection.

Inclusion occurs at a time when people seek to identify with members of a given group. Relationships of acceptance or exclusion, of ownership, of company, etc. are created. In the inclusion phase, each person tries to locate himself and find his position in the center or the periphery of the group, imagining the level of interaction, and what he expects to receive back, according Moscovici. Then the experimental structuring phase begins the restlessness with the distribution of power, competition for leadership, control of the activities of the members that make up the group, etc.

This is the phase of control where the central dilemma is related to being located in the group, located at the top, middle or base, positioning above or below the other members of the group. It is a phase replete of conflicts and sometimes confrontation. The last phase is the affection, which is evidenced in shared affections. 
It is common at this stage to search for emotional comfort with the consequent verbal or non-verbal communication of feelings of support, affection, envy, rejection, jealousy, etc. Schutzemphasizes that affection is based on the gradual establishment of emotional bonds, referring to intimate emotions, of close contact between two persons. Still according to this author it is imperative to go through these three phases so that the group activities are fruitful. It will then be up to the group leader to identify each moment their team goes through in order to facilitate their actions as well as the understanding and experience and ongoing development of each member of their team. However, developing a good level of relationship with people is not only the leader's responsibility. It is a responsibility of all involved and goes through the individual and organizational level, which makes constant training and human development programs a categorical imperative for those organizations that aim to achieve excellence. The experiences witnessed by the members of a group can create significant changes in the lives of the people who compose them:

Knowledge of the group dynamics of which the person is part helps to understand many of his actions and reactions. Ideas, knowledge, opinions, actions, behavioral expressions, beliefs, feelings, attitudes, values and philosophy of life of each member of the group are inputs in the process of global interaction. The reciprocal influence of the individual repertoire is inescapable: no one is immune to the exchange with other people in the group(Moscovici, 1985).

Another aspect that the leader must be aware of is the learning processes of group members, which tends to occur through the acquisition of new knowledge as well as the acquisition of new behaviors that effectively ratify the content learned. The moment the other exposes through speech their experience of life, there may be learning or at least an opening for learning. However, this practice presupposes that group members have conversational skills, that they master the acts of speech, and that they are skilled in the art of active listening.

Another theorist who helps us understand the dynamics of the groups is Kurt Lewin (apud Pichon-Rivière), one of the first to granted importance to the relationship between the human being and his circumstance, that is, his environment. Lewin aimed to investigate the influence that the environment exerted on the individuals, the relations that constitute it, as well as the way individuals act, react and organize as circumstances change. Enrique PichonRivière was a follower of Kurt Lewin and, intrigued by issues related to group processes, developed ideas and theories about groups, discussing the richness and complexity of their processes and the determinants responsible for the roles each member takes on of the group. Identifying these roles is one of the functions a skilled leader must have.

Pichon-Rivière analyzed three distinct moments in the development of the group:

1) Pre-task: period for which members demonstrate resistance to task and consequently change.

They engage in activities to spend time full of defensive techniques that end up generating great dissatisfaction, paralyzing the progress of the group. Such resistance is tied to the presence of basic fears, defined by Pichon-Rivière as "anxiety of loss" of what is known and safe;

2) Task: period in which members acquire some knowledge and skills that can be directed to

their anxieties and fears in order to appease them. It is the cure of group illness. The communication becomes clearer and more transparent, and the resistances are cooled. Thus, the group works in the search for transformation; 
3) Project: from this moment, what Pichon-Rivière designates as Project or Product, that is, strategies and tactics to produce changes that, in turn, would transform the subject again.

All these processes are dynamic and can circulate through all the members of the group. Attending to the roles represented by each of the group members, and especially their own roles, can give the leader greater potential to assist in building and excellence teams.

\section{CONCLUSION}

As John Donne put it, "no man is an island."We live in constant relation, because it is precisely in the relation and the conception of our ties with the people, that we structure our thinking, we choose or inherit our values and we constitute ourselves as people. Therefore, organizations, through their leaders, have to understand and be responsible for the variables that influence human interactions in order to, minimally, enable the individuals who are part of their teams to understand the functioning of the intricate intrapersonal dimension, that is, the Constant inner communication, the relations of alterity and group dynamics. All these aspects constantly influence the groups, compromise all their members and delimit the possibilities of the organization. We tried to score some of these variables that should be perceived by any and all leaders who wish to do a good job and aim to improve their skills to work with groups.

Groups are spaces where people occupy symbolically determined positions and these positions are responsible for the way in which the relations between people are constituted. The work of a leader, associated with respect for the plurality and importance of group work, reflects on simple loop learning that solidifies into automatic behaviors emerging from the social context in which we are inserted.

It is understood that this study should be based on the behavior of leaders and leads regarding the effectiveness of group work, because it is possible to develop leadership models that prioritize processes and results emerging from collective construction. This is a great step to understand the organizational environment context. 


\section{REFERENCES}

[1] Zimerman, D., Osório, L. C. Como trabalhamos com grupos[M]. Porto Alegre: Artes Médicas, 1997

[2] Pichon-Rivière, E. O processo grupal. 4. Ed[M]. São Paulo: Martins Fontes, 1991

[3] Senge, P. A quinta disciplina. 19. Ed[M]. São Paulo: Best Seller, 2005

[4] Fleury, M. T. L., Fleury, A. Construindo o conceito de competência. Revista de Administração Contemporânea, Curitiba, v. 5[M]. edição especial, 2001:183-196

[5] Ortega y Gasset, J. Meditações do Quixote[M]. São Paulo: Livro Ibero Americano Ltda., 1967

[6] Elkington, J. Canibais com garfo e faca[M]. São Paulo: Makron, 2001

[7] Schutz, W. Psicoterapia pelo encontro[M]. São Paulo: Atlas, 1978

[8] Moscovici, F. Desenvolvimento interpessoal. 3. E d[M]. Rio de Janeiro: Livros Técnicos e Científicos, 1985 